\title{
Joint Ventures in Russia (Regional aspects)
}

\author{
Daria V. Nesterova / Ludmilla N. Popova*
}

One of the economic policy priorities proclaimed by the Russian government concerns creating conditions for stimulating investments into the economy. However, government efforts in the struggle against inflation, including transactions on the open market, lead to capital outflow, thus hindering the investment process. Internal sources of investing turn out to be „blocked“, clearing the way for foreign investments and increasing their timeliness for the accepting country.

However, resources of foreign investors do not go to Russia's economy. The volume of direct foreign investments in 1994 was $2.3 \%$ of the volume of the world capital export per year. By June 1, 1994 14,000 enterprises with foreign capital had been written into the state register of Russia ${ }^{7}$. The reasons for this situation are obvious: unfavorable investment climate due to political and economic instability, imperfection and changeability of Legislation, onerous taxation system, undeveloped infrastructure.

The expected package of the necessary laws was not adopted by the former Duma; the law „On agreements in product sharing“ has not been passed, though it is rightly considered to be the indicator of readiness for mass attraction of foreign investments. Thus, the present legislation base leaves no hope for breakthrough in the sphere of foreign investments. In this connection we would like to attract attention to the opportunities which are opening today at the level of individual regions and regional strategy. Of the primary importance here is the government's adoption of the decree „on complex program of stimulating domestic and foreign investments into economy of the Russian Federation“, which is provided with the mechanism of mortgage insurance and guarantees of

Daria V. Nesterova, Associate Professor, Chair of Economics and Law, Faculty of Economics, Gorky State University Ekaterinburg, major areas of research interest: economic and law, public economics, labor management.

Ludmilla N. Popova, Associate Professor, Chair of Organizational and Economic Systems, Faculty of Economics, Gorky State University Ekaterinburg, major areas of research interest: international marketing, management.

7 Urinson Ya. (1994) Investment Climate in Russia and Attraction of Foreign Investments. Report of the First Vise Minister of the Economy of Russian Federation. Voprosy Economici 8/1994. p. 5. 
foreign investments. Worth noting is the fact that implementation of this mechanism is possible only through relying on regions, first of all on those possessing necessary resources, high liquidity and able to act as a guarantee. In accordance with these agreements the Regional guarantee fund was founded. It consists of gold and precious stones (as fixed proportion of gold and gems in total mining).

Another crucial event in this connection was the signing (Moscow, January 1996) of the agreement and Treaty on delimitation of jurisdiction and authority between bodies of the state power of the Russian Federation and bodies of the state power of the Sverdlovsk region, due to which there appear new possibilities both for developing and running regional economic policy and for attracting foreign investments in our region.

The Sverdlovsk region possessing one of the largest scientific and production potential in Russia. High-quality labour resources belong, at the same time, to the old industrial regions with high specific proportion of mining and processing industries, the technological core of which was being formed in the years of industrialization. The economy of the Sverdlovsk region is notable for high share of defense enterprises liable to conversion; it is characterized by weak social orientation marked in inadequate development of consumer goods and services production, and by a relatively imperfect infrastructure. The present structure of employment, reflecting the structure of economy, can be assessed as the sluggish one with poor conversion causing real and potential tension on the labour market.

Having at its disposal a number of competitive advantages such as rich raw materials base, relatively cheap and skilled labour resources, the Sverdlovsk region, at the same time, needs foreign investments for:

- developing the unclaimed scientific and technological potential of the defense enterprises liable to conversion;

- expanding and diversification export potential of the region, developing the channels of introduction of goods into world markets;

- setting up import replacing productions, developing consumer goods productions, food products and medicines;

- developing transport and communication, other branches of infrastructure.

Besides, Ural enterprises associate their hopes with foreign investors for creation of new jobs, attraction of advanced foreign technologies, and for getting profits in hard currency for the sake of capital accumulation and production upgrading. The real background of the above priority trends for foreign investments is as follows.

By September 1, 1995 in the Sverdlovsk region 145 enterprises (143 operating) with foreign investments had been registered; it was 3 times as much as in 1993. However, if in 1994 their number doubled, the 1995 period registered only 40\% growth. Within the same period the number of employees at Joint Ventures 
increased 3.5 times and comprised 3328 people or $0.5 \%$ of the total number of the employed at the enterprises and businesses in Ekaterinburg 8 .

The structure of joint ventures activity in table 1 shows that in 1994 in the production sphere there were $47.7 \%$ of joint and in 1996 the number reduced to 37.8\%; 36.2\% of joint ventures dealt with intermediate trade operations, in 1995 $61.1 \%$ were involved in this sphere, in $199412.8 \%$ of enterprises carried out research activity and in 1995 the number declined to 3.5\%.

Thus, the last 2 years witnessed the essential reorientation of enterprises' activity into spheres characterized by low capital capacity and high turnover which testify economic and political instability. Within the same period there was decline in the number of joint ventures operating in light, food and medical industries, thus giving the picture of generally unfavorable regime of Russian enterprises.

One can judge seriousness and stability of joint ventures' intentions by the data on putting capital assets into operation, by dynamics and trends of investments. Thus, if in 1994 industry accounted for $46.5 \%$ of the total volume of operating capital assets, including $19.2 \%$ of all capital investments, in 1995 industry accounted for only $12.4 \%$ of the volume of all introduced capital funds and $5.8 \%$ of capital investments.

The analysis of the structure of joint venture capital shows that those have been purely bilateral agreements where only the private capital operates. The top five natinal foreign investors, with reference to volume in the authorized fund of joint ventures, comprise Germany (49.8\% of the total value of foreign investments in the Sverdlovsk region); Sweden (26.6\%); USA (5.51\%); Switzerland (3.9\%); Cyprus (3.8\%) .

On the whole, the share of foreign partners in the authorized fund of joint ventures is growing steadily (although the growth rates have slowed down): in 1993 it equaled $32.9 \%$, in 1994 - 49.2\%, in 1995 - 49.5\%. Lately there have been changes in the ratio of foreign and Russian capital in some branches and spheres of activity (see table 2). Parity participation has been formed in industry; majority - in trade, sales and marketing spheres; minority - in science and scientific services.

8 Here and further the calculation were done on the basis of the data of the Sverdlovsk Regional Statistics Department for the period of 1994 and 1995 (January-October): On the activity of Joint Ventures.

9 It is interesting to compare these data with the first ten countries foreign investors in Russia according to the volume of investments into authorized funds (1994): USA, Honkong, Germany, Italy, Switzerland, Canada, Great Britain, Spain, Turkey, Belgium, China (Kommersant. 29/1995. p. 32-33) 
The economic potentials of joint ventures can be evaluated by the authorized fund: in 1995 its total volume was 48.7 billion roubles. Thus, on average each enterprise has 340.6 million roubles, or $\$ 756.8$ thousand (exchange rate: 4500 roubles to $\$ 1$ ). In industry, the average volume of the authorized fund runs to 2 million 726 thousand (taking into consideration that just one enterprise ABB"Uralelectrotyazhmash" accounts for \$1 million). Thus, the summarized profile of a joint venture can include the following features: the average staff is 23 people, its authorized fund runs to $\$ 757$ thousand, it is virtually divided between Russian and foreign partners equally, the priority activities are focused on intermediate trade and marketing. It is obvious that neither in its economic potential, nor in the activity direction, joint ventures can efficiently influence the region's economy, especially regarding the objectives connected with the attraction of foreign investments. Partially, this reflects the general investment climate in Russia However, the fact that the Sverdlovsk region possesses scientific and production potential, which in volume and quality sets it in the first five regions of Russia (although it accounts for only $0.02 \%$ of all foreign investments allocated in Russia) means that there exists a regional set of reasons which demand thorough research and analysis. It is evident, today, that we need the package of documents to represent regional investment climate, to includer foreign investors as well.

Table 1: Allocation of Joint Ventures in spheres

\begin{tabular}{|l|rr|rr|}
\hline Spheres of economy & \multicolumn{2}{|c|}{1994} & \multicolumn{2}{|c|}{1995} \\
\hline & $\begin{array}{r}\text { number of } \\
\text { enterprises }\end{array}$ & $\begin{array}{r}\text { \% to total } \\
\text { volume }\end{array}$ & $\begin{array}{r}\text { number of } \\
\text { enterprises }\end{array}$ & $\begin{array}{r}\text { \% to total } \\
\text { volume }\end{array}$ \\
\hline Total number of operating Joint & 94 & 100 & 143 & 100 \\
Ventures (in spheres) & & & & \\
\hline 1. Industries including: & 40 & 42,5 & 28 & 19,5 \\
- ferrous metal industry & 2 & 5,0 & 1 & 3,6 \\
- non-ferrous metal industry & 4 & 10,0 & 4 & 14,2 \\
- chemical and petrochemical & 2 & 5,0 & - & - \\
- engineering and metal processing & 13 & 32,5 & 12 & 42,8 \\
- timber and cellulose & 11 & 27,5 & 5 & 17,8 \\
- sight & 4 & 10,0 & 2 & 7,1 \\
- food & 2 & 5,0 & 1 & 3,6 \\
- medical & 1 & 2,5 & - & - \\
• others & 1 & 2,5 & 3 & 10,9 \\
2. Transport and communication & 2 & 2,2 & 4 & 3,4 \\
3. Construction & 3 & 3,0 & 7 & 4,9 \\
4. Trade and public catering & 28 & 29,8 & 82 & 57,3 \\
5. Purchasing and sales & 3 & 3,2 & 3 & 2,0 \\
6. Information services & 1 & 1,1 & - & - \\
\hline
\end{tabular}




\begin{tabular}{|c|c|c|c|c|}
\hline 7. Marketing activity & 3 & 3,2 & 3 & 2,1 \\
\hline 8. Science and scientific service & 12 & 12,8 & 5 & 3,5 \\
\hline 9. Other spheres & 2 & 2,2 & 2 & 1,4 \\
\hline
\end{tabular}

Table 2: Partners Share in the authorized fund of a Joint Ventures (\%)

\begin{tabular}{|l|rr|rr|}
\hline Spheres of economy & \multicolumn{2}{|c|}{1994} & \multicolumn{2}{|c|}{1995} \\
\cline { 2 - 4 } & foreign & russian & foreign & russian \\
\hline Total number of operating Joint & 49,2 & 50,8 & 49,5 & 50,5 \\
Ventures (in spheres) & & & & \\
\hline 1. Industries including: & 62,4 & 37,6 & 50,0 & 50,0 \\
- ferrous metal industry & 40,0 & 60,0 & 40,0 & 60,0 \\
- non-ferrous metal industry & 78,8 & 21,3 & 51,5 & 48,5 \\
- chemical and petrochemical & 25,7 & 74,3 & - & - \\
- engineering and metal processing & 32,5 & 67,5 & 49,3 & 50,7 \\
• timber and cellulose & 80,7 & 19,3 & 75,3 & 24,7 \\
- sight & 50,0 & 50,0 & 50,0 & 50,0 \\
• food & 52,5 & 47,5 & 48,0 & 52,0 \\
• medical & 35,0 & 65,0 & - & - \\
- others & 49,0 & 51,0 & - & - \\
2. Transport and communication & 35,0 & 65,0 & - & - \\
3. Construction & 27,6 & 72,4 & 36,5 & 63,5 \\
4. Trade and public catering & 35,0 & 65,0 & 64,7 & 35,3 \\
5. Purchasing and sales & 55,6 & 44,4 & 61,9 & 38,1 \\
6. Information services & 51,0 & 49,0 & - & - \\
7. Marketing activity & 64,0 & 36,0 & 99,7 & 0,3 \\
8. Science and scientific service & 64,2 & 35,8 & 49,7 & 50,3 \\
\hline
\end{tabular}

